\title{
Determination Of The Performance Measure Of Executive Compensation
}

\author{
Shirley Chuo, Ph.D, American InterContinental University, USA \\ Jean Emmanuel Fonkoua, Argosy University, USA \\ Dennis Pollard, Ph.D, California State Fullerton University, USA
}

\begin{abstract}
This paper investigates the principal-agent model of executive compensation through an empirical study of the interaction between CEO compensation and firm performance. As a multi level regression analysis that specifically shows the weight of the variance of the main independent variable, above and over the other independent variables, the stepwise multiple regression is employed to induce a statistical model of the pay-performance sensitivity. The stepwise multiple regression offers insights into the different weight assigned to the performance measure. In this respect, variances of the variables related to the change in the market value of firms are specifically weighted against each other in order to determine specific characteristics of the payperformance relationship. The analysis is consistent with the agency theory that firm' executives take advantage of the lack of control by firms' owners to pursuit their personal interests. As the United States' economy tumbles, the change in CEO total compensation does not seem to follow the accounting criteria of performance measures typically specified in management compensation contracts. The study reveals a lack of relationship between CEO compensation and firm performance. The link running from the change in the market value of firms and the change in CEO total compensation is flawed. The incentives faced by shareholders to discipline executives would be able to increase the performance of firms. It would be absurd for the compensation committee to rely on the single firms' total assets value as the performance measure of CEO compensation. Other performance vehicles, such as returns, earnings, and cash flows should be considered in the determination of executive compensation.
\end{abstract}

\section{INTRODUCTION}

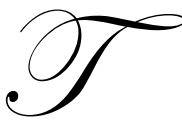

he agency theory states that the absence of control by firms' owners (principals) results in managers' of firms (agents) taking advantage of their positions to obtain personal benefits (Ueng, Wells, and Lilly, 2000). Also called the principal-agent model of executive compensation, insights of the agency theory are used to enrich the pay-performance sensitivity that relates executives' pay to the performance of firms. The agency theory recommends that firms should set up a system of compensation policies that align executives' pay with firms' performance measures. Under this system, the development of a compensation plan should tie the interests of firms' executives to the ones of the owners of firms. The proposed study links CEO total compensation to firm performance as an attempt to help compensation committees determine the optimal remuneration of firms' executives. The model empirically relates the change in CEO total compensation to the change in the market value of firms; more especially, this paper examines whether the change in executives' compensation contracts is related to the change in compensation vehicles such as returns, cash flows, earnings, and assets.

\section{PREVIOUS LITERATURE}

Researchers employ the agency theory as the lens, through which managers' pay arrangement should be analyzed when they proposed a quantitative technique that views the performance of firms as the accounting measure of firms' value, and thus investigate its relationship to executive compensation package. Pioneered by Berle and Means (1932), issues related to the separation of ownership and control, were raised in the corporate governance scheme. Thereafter, great strides in assessing management incentives and the performance of firms were made 
possible by the use of statistical tests. Several studies on the pay-performance sensitivity then laid the foundation for an in-depth empirical investigation on the relationship between executive compensation and firm performance.

Jensen and Murphy (1990) contend that CEOs compare their personal profits and costs when undertaking particular investments. More explicitly, the separation of ownership and control carries the disadvantage of firms' owners to lack a straight influence on companies; which in turn, opens door to the possibility for firms' executives to pursue their own interests. In the same line of reasoning, Yurtoglu and Haid (2005) argue that a large number of shareholders create an atmosphere where managers' goals may deviate from shareholders' best interests because dispersed ownership limits the possibility for firms' owners to monitor the activities of firms' executives, and thus reduces the possibility for shareholders to put an end to the actions of inefficient firms' executives. Based on this consideration, business and financial models of executive compensation link greater effort to higher pay, and thus tie a reward scheme for executives to the performance of firms.

According to Nisenzoun (2003), Jensen and Murphy were the first to quantify the relationship between the remuneration of CEOs and the value of shareholders in an article published in 1990. Using CEOs' salary plus bonus as the measure of CEO compensation, Jensen and Murphy found that every thousand dollar change in accounting earnings of firms the United States in the years 1974-1986 results in an increase of CEOs' salary and bonus of less than a dollar. The study provides valuable insights on the issue of the statistical and financial importance in reference to the pay-performance relationship. The research found the accounting earnings of firms to be statistically related to CEOs' salary and bonus, but rejected its economic importance in the sense that adequate incentives for effort would not result in such a low pay-performance relationship. In an attempt to provide a more important outcome on the issue of incentives for executives, Jensen and Murphy (1990) redefined CEO compensation in order to take into account additional variables in the measure of the wealth of firms' executives. The permanent increase in base pay, the stock ownership, the stock options, and the threat of dismissal were included in the definition of CEO compensation. The result failed to strengthen the economic validity of the test even though the CEO wealth rose to $\$ 3.25$ for each additional $\$ 1,000$ increase in accounting earnings of firms. In spite of the inclusion of other variants in the definition of executives' compensation for a more realistic result, the alternative measure of CEO total compensation did not provide a convincing illustration of the association between earnings and profits. Schaefer (1998) argues that the slender evidence of Jensen and Murphy (1990) is due to an inelegant estimation model and claims that it is inappropriate to ignore the effect of other compensation vehicles in the function employed to generate executive compensation. Critics in reference to the absence of other explanatory variables in the setup of most models of executive compensation thus lead to the consideration of other performance variables in the determination of executive compensation.

\section{METHODOLOGICAL ANALYSIS AND DATA SOURCES}

The principal-agent model of executive compensation views the role of managers (agents) as maximizer of the wealth of shareholders (principals) by aligning pay with performance. Empirical evidence demonstrates that firms consistently search for reliable performance measures to tie firm performance to managers' best interests. According to Ashley and Yang (2004), stock- and equity-based performance measures determine the executive compensation package. Whether stock-based performance measures is utilized to stimulate risk-taking actions of executives, reward vehicles, such as stock options and restrictive stock are generally employed to remunerate managerial actions that produce growth. This paper examines the weight of the variance of the elements of the performance measure of firms in their relationship to CEO total compensation.

CEO total compensation $=\mathrm{f}($ performance of firms $)$

Theoretical evidence shows that accounting measures of the market value of firms is used to proxy firms' performance in the principal-agent model of executive compensation (Ashley and Yang, 2004). Governing boards of large firms thus tend to rely on compensation contracts to tie senior executives' actions to financial goals of stabilizing the growth of firms, so as to avoid the volatility of the market value of firms. In this respect, the change in the market value of firms manifests the search for reliable performance measures by the compensation committees' to reward the effort of executives' actions. The change in CEO total compensation is thus predicted to be related to the change in the accounting market value of firms. 
In most studies of executive compensation, accounting earnings appear to be an important determinant of the performance measure for the chief aim of determining CEO compensation. Some researchers have utilized firms' total profit of firms to proxy the performance measure (Jensen \& Murphy, 1990; Nisenzoun, 2003). The use of the accounting earnings of firms to evaluate the performance measure is supported by the view that the maximization of the net worth of firms' executives is the performance criterion tied to the annual profit. According to Ashley and Yang (2004), large firms tend to rely more on stock-based performance measures to reward managers. Based on this view, executives' total compensation is related to stock returns, and firms' total sales are used as a proxy for stock returns. Cheng, et al. (1996) found that managers use alternatives such as cash flows when irregularities in earnings are observed. Moreover, Ashley and Yang (2004) contend that earnings generate a performance measure that includes noise; consequently, firms possess lesser power to predict future profitability, and alternatives, such as cash flows from operations should be included as a performance measure. In the same line of reasoning, Barth, et al. (2001) found that current cash flows forecast future cash flows better than earnings in a short term period, and Teitelbaum (2003) determined that investors lower expectations of future earnings and focus on cash flows resulting from firms' operations. The obvious argument is that the compensation committee includes cash flows to predict future profitability, and thus assigned a certain weight to cash flows in executives' compensation contracts. Total cash flows are thus employed to evaluate the cash flows from operations of firms. Researchers also explain executive compensation by employing firms' total asset value (Schaefer, 1998). It is argued that firms with large asset value have more hierarchical level of responsibility and firms' executives must deal with the obligations attached to duties at the different levels of firms; an intense effort of firm's executives should thus result in higher pay. The asset value of firms is thus utilized to evaluate the total assets.

The strategy crafted by the compensation committee to support the total compensation package of executives should relate to earnings, returns, cash flows, and assets. Based on the above reasoning, the empirical strategy in the determination of executives' compensation describes the change in CEO total compensation as a function of the change in firms' total profit, the change in firms' total sales, the change in firms' total cash flows from operations, and the change in firms' total asset value.

Change in CEO compensation $=\mathrm{f}($ change in earnings, change in returns, change in cash flows, change in assets $)$

The change in stock returns and the change in firms' total asset value are expressed using the growth rate of the two variables. Like Baber, et al. (1999), this research utilizes the lagged base salary in order to scale the magnitude of the change in CEO total compensation; it is a way to minimize the previous period's performance on the measure of CEO total compensation. Following Ashley and Yang (2004), the change in cash flow and the change in earning are deflated by the beginning book value of total equity in order to capture firms' scale effects. Prior research has also demonstrated the need to avoid potential bias and eliminate the presence of outliers through the use of the percentage change of the values of the original variables. This technique in statistical modeling is mostly used to correct problems associated with skewed data, non stable variance, and non linear relationship. All the variables are thus expressed in percentage change of the numerical values of the original variables in two consecutive years in order to squeeze together larger values and stretch out smaller values.

The statistical technique used necessitates an empirical evaluation in light of the stepwise multiple regression. This procedure involves a regression in steps that compares the variables for the chief aim of assessing the importance of the independent variables. More specifically, this procedure shows the weight of the variance in the change in CEO total compensation that can be accounted for by the change in returns, the change in cash flows, the change in earnings, and the change in assets. The empirical measure requires a four-bloc regression analysis technique, which reflects the four independent variables. The model departs from the least important determinants to arrive at the most important one on the basis of the weight of the variance of each independent variable. The setup of the regression is so that the change in returns, the change in cash flows, the change in earnings, and the change in assets are eliminated at each level of the regression model. The study yields a breakdown of the total variance in four sets of regression equations and shows more specifically the weight of the variance in CEO total compensation that can be accounted for by each of the independent variable. 
At the lower level (level one), the regression equation relates CEO total compensation to the four independent variables. At this level, the model expresses the weight of the variance in CEO compensation that can be accounted for by the change in returns, the change in cash flows, the change in earnings, and the change in assets. The explicative variables are then eliminated at each step of the regression equation to arrive at a most parsimonious model. At the higher level (level four), the regression equation associates the CEO total compensation only with the variable that possesses the strongest weight, which is measured by its total variance in the model. At the base level (level one), CEO total compensation is predicted as a function of a linear combination of the change in returns, the change in cash flows, the change in earnings, and the change in assets through the following equation:

\section{Level 1}

CEO total compensation $=\alpha+\beta \mathrm{X}_{1}+\eta \mathrm{X}_{2}+\lambda \mathrm{X}_{3}+\gamma \mathrm{X}_{4}+\xi$

The parameter $\alpha$ represents the intercept; like the indexes $1,2,3$, and 4 , the parameters $\beta, \eta, \lambda$, and $\gamma$ are associated with either of the following variables: change in returns, change in cash flows, change in earnings, or change in assets, and the parameter $\xi$ refers to the standard error term. The subsequent levels (level 2 to 4 ) exclude the independent variable based on their unimportance in the CEO compensation model and analyze the weight of the variance of CEO compensation that can be accounted for by the remaining independent variables. A simple statistical model for estimating the subsequent model of the stepwise multiple regression expressed the CEO total compensation equation as a function of the remaining variables in the following order:

\section{Level 2}

CEO total compensation $=\alpha+\eta \mathrm{X}_{2}+\lambda \mathrm{X}_{3}+\gamma \mathrm{X}_{4}+\xi$

\section{Level 3}

CEO total compensation $=\alpha+\lambda \mathrm{X}_{3}+\gamma \mathrm{X}_{4}+\xi$

\section{Level 4}

CEO total compensation $=\alpha+\gamma \mathrm{X}_{4}+\xi$

Delving into equations (4), (5), (6), and (7) to explore their practicability, the model commences with the utilization of four sets of explicative variables, the variable with the least weight in total variance is then eliminated at each level of the regression model to finally arrive at the most parsimonious equation composed of the variable with the strongest weight, measured by its total variance in the CEO total compensation model. The stepwise multiple regression is employed as a way to explicitly estimates the independent variables; this technique is meant to avoid a misrepresentation of the relationship among the predictors at the CEO total compensation level. The desire to use the stepwise multiple regression is motivated by the possibility to remove possible distortions in the regression weight of the estimates; it is a technique to eliminate the bias in the estimates for standard errors of the mean.

Recall that the main purpose of the multi level model is not to depict the parameters of the observable variables of CEO total compensation, but to distinguish between the weights of the variance of the independent variables in the determination of the performance measure of CEO total compensation. It is noteworthy that the coefficients $\beta, \eta, \lambda$, and $\gamma$ are positive if the changes in the monetary benefits attached to the CEO position gets higher as the change in returns, the change in cash flows, the change in earnings, and the change in assets increase. Although the focus is on the variance of the elements able to significantly impact the remuneration of CEOs, attention is also given to the positive or negative nature of the relationship between CEO total compensation and its determinants. Statistically, this encompassing approach is aimed to guide policy makers, and help scholars prevent 
erroneous inference when debating on issues related to CEO compensation.

Secondary data on CEOs' salary and the book value of total equity for the year 2007, so as CEO total compensation, firms' total profit, firms' total sales, firms' total cash flows from operations, and firms' total asset values for the two consecutive years 2007 and 2008 are essential components of the groundwork for the empirical testing of the theoretical analysis. Mergent and Hoover are two detailed and comprehensive data source used in this research. Both publications report business, financial, and marketing figures of firms of the United States. Similar to Mergent, Hoover is a broad database that publishes statistical data on business, financial, and marketing information of firms. Unlike Hoover, Mergent tracks extensive data on private and public companies in a lot of countries. In the Hoover's source, financial, marketing, and business information of each company are disclosed in a file, and the researcher has to look into a big document for the information needed. Whether the Mergent's database is utilized in this research to extract the fortune 500 firms, which serves as the main source of the investigation in the determination of the performance measure of CEO total compensation, the Hoover's database is employed to extract the accounting business and financial information of large publicly held companies. A pool of 103 firms from the Fortune 500 firms of the United States appears to have complete information needed in order to perform the empirical analysis. The non selection of the other firms is due to incomplete information, mostly related to data on CEO total compensation.

The analysis adopts the exceptional convention of shifting the focus on the amount of the financial variables in a time period of the year 2008. CEO total compensation is the reported short-term and long-term components of executive compensation, which include the base salary, the annual bonus, the stock options, and the long-term incentive plans. The cash flows from operations include short term investments that can be rapidly converted into cash. As the measure of returns, the revenue is the total sales generated from operations. The firms' total assets value is evaluated as the current assets plus the non-current assets; they comprise both assets that can be converted into cash within a year and those that are not allocated to net fixed assets. The book value of total equity is computed as the addition of the preferred stock equity to the common stock equity; it is the residual value of the firm after all the liabilities have been deducted. As the measure of earnings, the firms' total profit is employed; it is the total net income after accounting for all business actions such as income taken after taxes.

\section{Test Results}

Descriptive statistics (the mean, the standard deviation, the minimum, the first quartile, the median, the third quartile, the maximum, and the number of observations of the sample firms of the United States for the year 2008 are provided in the table below:

Table 1

Summary statistics

\begin{tabular}{|l|c|c|c|c|c|c|}
\hline & Salary & Total Compensation & Returns & Cash flows & Earnings & Assets \\
\hline Mean & 1058390 & 8530533 & 16660665050 & 3604765050 & 547191260 & 41448500970 \\
\hline $\begin{array}{l}\text { Standard } \\
\text { Deviation }\end{array}$ & 412217 & 6502854 & 4062310 & 1356760 & 2937855680 & 1373150 \\
\hline Minimum & 100000 & 790600 & 497000000 & 800000 & -13402000000 & 732400000 \\
\hline $\begin{array}{l}\text { Lower } \\
\text { Quartile }\end{array}$ & 854167 & 3722320 & 5517300000 & 253900000 & -8000000 & 4415800000 \\
\hline Median & 1007692 & 6676874 & 7695000000 & 682000000 & 305400000 & 11861000000 \\
\hline $\begin{array}{l}\text { Upper } \\
\text { Quartile }\end{array}$ & 1127597 & 11964632 & 15849000000 & 2277000000 & 1215000000 & 32686000000 \\
\hline Maximum & 2769365 & 33386016 & 405607000000 & 116016000000 & 13400000000 & 1309639000000 \\
\hline Sample Size & 103 & 103 & 103 & 103 & & 103 \\
\hline
\end{tabular}

Values of the mean and the standard deviation of all variables reveal substantial differences across levels of total compensation, returns, cash flows, earnings, and assets. Negative values of the minimum and the lower quartile of the earning variable associated with positive values of the minimum and the lower quartile of the total 
compensation variable deliver a message inconsistent with the earnings' enhancing effect of CEO compensation. Based on the pay-performance relationship, a compensation system that rewards executives if a certain quota is met should be able to penalize executives if firms do not realize profits. This result translates into the extraction by CEOs of certain amount of benefits even when firms are losing money. In this prospect, it is apparent that the lack of a relationship between CEO total compensation and firms' earnings opens door to further investigation. The spread of data around the mean (coefficient of variation) and the spread within data (quartile coefficient of dispersion) may be useful tools for further analysis of the observations. The coefficient of variation $\left(\mathrm{C}_{v}\right)$ and the quartile coefficient of dispersion (QCD) are both appropriate tools for data analysis since they describe respectively the variation in the magnitude sample values and the dispersion within data. The coefficient of variation is estimated as:

$\mathrm{C}_{v}=\frac{\sigma}{\mu}$

$\mathrm{C}_{v}$ represents the coefficient of variation, $\sigma$ stands for the standard error of the mean, and $\mu$ denotes the mean value of the variables. As an index of the relative internal variability, the measure of dispersion is used to gauge scatter; the smaller the coefficient of variation, the more equitable the statistic distribution of data; in other words, the higher the coefficient of variation, the more dispersed the data. An alternative way to analyze the data is through the quartile coefficient of dispersion, which is given by the formula below:

$$
\mathrm{QCD}=\frac{\text { ThirdQuartile }- \text { FirstQuartile }}{\text { ThirdQuartile }+ \text { FirstQuartile }}
$$

In the above equation, the expressions "FirstQuartile" and "Thirdquartile" represent respectively the lower and the upper quartiles provided by the descriptive statistics. Using formula (8) and (9), computation of data from table one summarizes the variability and the dispersion of the variables salary, total compensation, returns, cash flows, earnings and assets whose results are given in the table below:

Table 2

Variation and dispersion of data

\begin{tabular}{|l|c|c|c|c|c|c|}
\hline & Salary & Total Compensation & Returns & Cash flows & Earnings & Assets \\
\hline Spread around mean & 0.39 & 0.76 & 0.00002 & 0.00004 & 5.37 & 0.000003 \\
\hline spread within data & 0.14 & 0.53 & 0.48 & 0.80 & 1.01 & 0.76 \\
\hline
\end{tabular}

Values of the above table translate into dataset with minimal variation and dispersion. With respect to the position of the variables relative to the mean, the dataset displays values bunched around the mean, except for the earnings variable that reveals noticeable variability. With respect to the spread within data, the earnings variable shows a dispersed distribution. Abstracting from other variables, it can be argued that huge fluctuations in earnings characterize large firms of the United States. A focus on the total compensation and the earnings variables when the other variables are not taken into consideration infers that CEOs' pay tend not to be in line with CEOs' contribution to the performance of firms, which contradicts the logic governing the pay-performance relationship that greater effort leads to higher pay. The following table depicts the relationship between the explained and the explicative variables; it also provides a summary of the coefficients in their levels (one, two, three, and four) of the stepwise multiple regression in a more precise manner. 
Table 3

Regression results

\begin{tabular}{|l|c|c|c|c|}
\hline \multirow{2}{*}{ Independent variables } & \multicolumn{4}{|c|}{ Dependent variable (Change in CEO total Compensation) } \\
\cline { 2 - 5 } & Level 1 & Level 2 & Level 3 & Level 4 \\
\hline Change in Assets & $0.26(2.39)[0.02]$ & $0.26(2.54)[0.01]$ & $0.26(2.71)[0.08]$ & $0.26(2.70)[0.08]$ \\
\hline Change in Earnings & $-0.04(-0.38)[0.70]$ & $-0.04(-0.37)[0.71]$ & $-0.04(-0.36)[0.72]$ & \\
\hline Change in Returns & $0.02(0.18)[0.86]$ & $0.02(0.16)[0.88]$ & & \\
\hline Change in Cash Flows & $0.01(0.10)[0.92]$ & & & \\
\hline Summary Statistics (Weight of the independent variables at the different levels) & \\
\hline Adjusted R & 0.03 & 0.04 & 0.05 & 0.06 \\
\hline $\mathrm{R}^{2}$ change & 0.00 & 0.00 & 0.00 & 0.00 \\
\hline $\mathrm{F}$ & $1.81[0.13]$ & $2.44[0.07]$ & $3.68[0.03]$ & $7.30[0.01]$ \\
\hline $\mathrm{F}$ change & 1.81 & 0.01 & 0.03 & 1.13 \\
\hline
\end{tabular}

Note. Values enclosed in parentheses represent t-statistics and values enclosed in brackets denote probabilities.

An important feature of the regression results provided by the above table is given by the identification of the variables $X_{1}, X_{2}, X_{3}$, and $X_{4}$. The link running from the change in the market value of firm to the change in CEO total compensation regards $\mathrm{X}_{1}, \mathrm{X}_{2}, \mathrm{X}_{3}$, and $\mathrm{X}_{4}$ as the representation of change in cash flows, change in returns, change in earnings, and change in assets respectively. Whether the variable with the lesser weight in total variance in the CEO compensation equation is identified as the total cash flows from operations, the variable with the strongest weight in total variance represents the firm total asset value. A blinker view in the above table reveals that the $\mathrm{R}^{2}$ change remains constant at all level of the CEO total compensation model as the variables with the minimal weights in variance are gradually eliminated in subsequent models. A move from the base to the subsequent models of the regression equations shows a one percent increase in the value of the adjusted $\mathrm{R}^{2}$ at each level of the CEO compensation equation. It commences with a value of $3 \%$ in the base model to arrive at a most parsimonious model with the explanatory power of the assets variable reaching a peak at $6 \%$. In light of the values of the adjusted $\mathrm{R}^{2}$, the empirical reasoning suggests a very poor fit of the explanatory power of the independent variables.

Turning to the F-statistic, the fit of the estimated base model (level 1) appears insignificant at the $10 \%$ level of significance. The F-statistic of the base model reveals an F-value of 1.81 with the associated p-value of 0.13 ; this clearly indicates that the regression of the base model is not significant at the conventional level of significance. Based on the F-values of the estimated models, the empirical reasoning suggests the base model to be dropped from the analysis since it does not meet the requirements for comments. The F-value of the base model thus provide support to the argument that the cash flows from operations is not considered as a variable able to impact the performance measure in the determination of CEO total compensation. The F-values of the regression equations of the subsequent models of the CEO total compensation model display important patterns of 7\%, 3\%, and $1 \%$ level of significance; these F-values of the subsequent levels seems statistically well suited at the $10 \%$ level of significance. The regression results thus confer the greatest benefit in the exploration of performance criteria, such as returns, earnings, and assets, specified in CEO compensation contracts.

The estimated results provide arguments that run counter to the theory of executive compensation specified in compensation contracts and unease the financial logic of the pay-performance relationship. Cash flows as a performance measure is not in sync with returns, earnings, and assets in the determination of executive compensation. Recall that the financial literature stresses on the ability of current cash flows to predict future cash flows better than current aggregate earnings in a short term period. The estimated result systematically contradicts the argument of Barth, et al. (2001) that a certain weight is assigned to cash flows from operations in the executives' compensation contract. The estimated pay-performance relationship is in line with the argument of Perel (2003) that the empirical evidence presents no rational basis able to explain higher executive compensation. The empirical results also show support to the reasoning of Nisenzoun (2003) that CEO compensation is not consistent with the overall performance of firms. This result also validates the public perception that CEO compensation is out of control. 
After the variable cash flows is excluded from the regression equation, the model acknowledges the variables returns and earnings in the model at the CEO total compensation level. In light of the F-values of respectively $7 \%$ and 3\% level of significance, these two variables appear to be important determinants of CEO total compensation. However, the financial validity of the CEO compensation enhancing effects of returns and earnings seems to be distorted by the insignificant negative value of the earnings variable coupled with the insignificant positive value of the returns variable. The regression equations consider returns and earnings variables to be determinants with lesser weight in total variances in the CEO total compensation model. Moreover, the returns and earnings variables display a statistical t-value of respectively $12 \%$ and $28 \%$ confidence level in the determination of CEO total compensation; they are insignificant at the $10 \%$ level of significance. More explicitly, the earnings and returns variables are not statistically different from zero in the in the determination of CEO compensation contracts. Although these two variables are useful in the determination of CEO total compensation, their weights measured in total variance appear very weak driving the two variables to be insignificant at the conventional level of significance.

At the highest level, the model composed of the total assets as the only independent variable indicates statistically significant F-value of $1 \%$ level of significance. The statistical result reveals that the link running from firms' total asset value to CEO total compensation is statistically strong. This empirical result provides support to the idea that the total assets value is particularly sensitive in the determination of CEO total compensation. The quantitative assessment of the causality relationship between CEO total compensation and firms' total asset value is also analyzed through the evaluation of the t-statistic. With t-statistic values of 2.70 and the associated probabilities of $8 \%$ level of significance, the assets variable is significant at the $92 \%$ confidence level. The value of 0.26 , which determine the reaction of the change in CEO total compensation to a variation in the change of firms' total assets value translate into a positive influence of the reaction of CEO total compensation to an increase in firms' assets. More precisely, the model predicts an increase of CEO total compensation of $2.6 \%$ for every $10 \%$ increase in firms' total assets value. This result provide a strong support to the argument of Schaefer (1998) that the total asset value of firms is the main determinants of CEO compensation; it also explicitly ascertains a viewpoint conforms to the financial reality that CEO compensation should be linked to duties attached to CEOs' position in firms.

The objective of this research is to perform a quantitative study that tests the determinants of executive compensation under the criteria of the performance measure. The research investigates whether the compensation committee relies on the accounting measure of firms' value when designing executive compensation contracts. The research deeply looks into the weights of the variance of the change in cash flows, the change in returns, the change in earnings, and the change in assets in the accounting performance criteria of CEO total compensation. Basically, the investigation relates the total compensation package of executives to firms' total profit, firms' total sales, firms' total cash flows from operations, and firms' total asset value. In the process of answering the above questions, an additional discovery is made that lends itself to the ineffectiveness of the emphasis that investors placed on cash generated by firms' operations on CEO total compensation. It appears that discounting promises on future earnings through cash generated by firms' operations has any influence on the determination of CEO total compensation. This discovery comes with an in-depth understanding of a broad definition of the accounting determinants of executive total compensation.

Specifically, cash flows is not aligned with returns, earnings, and assets in the determination of executive compensation measure because the quantitative assessment of the causality relationship between CEO compensation and firm performance ignores the potential influence of the cash flows variable in the determination of CEO compensation. Even though returns and earnings are considered important elements in the determination of CEO total compensation, their insignificant effect deliver a message inconsistent with the economic reality since executive compensation should be aligned with the accounting measures of returns and earnings variables. Only the change in total asset value appears to be positive and statistically significant. The regression results reveal an increase in total asset value of a little more than a quarter of percentage point for every one percent increase in CEO total compensation. Even though the strong positive influence of the change in total asset of firms on CEO total compensation seems appropriate, the silent nature of returns and earnings translate into the general idea that compensation committees do not exhibit a willingness to adapt to the current market situation marked by the public constant grief about excessive executive compensation. Management actions do not result in successful performance of firms because of the distorted relationship between the actions of firms' executives and the corporate goals. It is 
absurd that the change in firms' total assets value by itself explains the change in executive compensation package. Compensation committees should definitely move beyond firms' total assets value and assigns a certain weight to alternative performance measure (earnings, returns, and cash flows) in the determination of executive compensation.

\section{SUMMARY AND CONCLUSION}

The agency theory suggests that firms interested in ensuring that corporate executives act in the shareholders' best interest should design compensation policies that tie the remuneration of firms' executives to the performance of organizations. The effectiveness to link executive compensation to the market value of firms is designed by estimating the magnitude that the change in accounting measures of cash flows, returns, earnings and assets exert on the change in CEO total compensation. The assessment of the non alignment of performance criteria defined in executive compensation contracts is evaluated using the stepwise multiple regression, which statistically weights the variances of the independent variables against each other. Inconsistent with the financial logic that tie the executive welfare to the accounting criteria of performance measures, the empirical results reveal the exclusion of cash flows as determinant of executive compensation; earnings and returns are considered as determinants of executive compensation; however, the insignificant nature of both variables delivers a message to policy makers in reference to a reexamination of executive compensation package. From the empirical standpoint, the link running from assets to executive compensation is positive and significant. The statistical results finally support the idea that it is only the firms' total asset value that plays an important role in the determination of executive compensation. The exclusion of cash flows, the zero effects of returns and earnings, and the strong positive influence of assets on CEO compensation offer the ability to pinpoint huge discrepancies in executive compensation contracts; it also pertains to demonstrate that executive compensation is in need of reforms.

\section{REFERENCES}

1. Ashley, A., \& Yang, S. (2004). Executive compensation and earnings persistence. Journal of Business Ethics, 50(4), 369-382.

2. Baber, W., Kang, S., \& Kumar, K. (1999). The explanatory power of earnings levels vs. earnings changes in the context of executive compensation. Journal of Accounting Research, 74, 459-472.

3. Barth, M., Cram, D., \& Nelson, K. (2001). Accrual and the prediction of future cash flows. The accounting Review, 76, 27-58.

4. Berle, A., \& Means, G. (1932). The modern corporation and private property. New York: MacMillan.

5. Cheng, A., \& Yan, S., (2002). Direct and cross effect of the persistence of earnings and cash flow from operations on their incremental information contents. Working paper, University of Houston.

6. Jensen, M.C., \& Murphy, K.M. (1990b). Performance pay and top management incentives. Journal of Political Economy, 98, 225-264.

7. Nisenzoun, F. (2003). The correlation of executive compensation and shareholder wealth. Retrieved January 10, 2007, from http://wwwecon.stanford.edu/academics/Honors_Theses/Theses_2003/Nisenzoun.pdf

8. Perel, M. (2003). An ethical perspective on CEO compensation. Journal of Business Ethics, 48, 381-391.

9. Schaefer, S. (1998). The dependence of pay-performance sensitivity on the size of the firm. The Review of Economics and Statistics, 80(3), 436-443.

10. Teitelbaum, R. (2003). Playing the dividend market. Fortune, 146(12), 77-82.

11. Ueng, C.J., Wells, D.W., \& Lilly, J.D. (2000). CEO influences and executive compensation: Large firms vs. small firms. Journal of Managerial Finance. 26(8), 3-12.

12. United States Business, Financial, and Marketing Source. Hoovers Online [Data file]. Retrieved from http://premium.hoovers.com.ezproxy.libraries.claremont.edu

13. United States Business, Financial, and Marketing Source. Mergent Online [Data file]. Retrieved from http://www.mergentonline.com.ezproxy.libraries.claremont.edu

Yurtoglu, B. B., \& Haid, A. (2005). Ownership structure and executive compensation - The case of Germany. Retrieved July 12, 2007, from http://www.fep.up.pt/conferences/earie2005/cd_rom/Session\%20VII/VII.A/burcin.pdf 


\begin{tabular}{|c|c|c|c|c|c|c|}
\hline Company & Salary & Compensation & Returns & Cash Flows & Earnings & Assets \\
\hline Abbot Laboratories & 1795471 & 28335494 & 29527600000 & 5079600000 & 4880700000 & 422419200000 \\
\hline AES Corp & 999000 & 74009 & 16070000000 & 00000 & 1234000000 & 34086000000 \\
\hline Avon Products Inc & 1375000 & 11055012 & 10690100000 & 1114800000 & 875300000 & 6074000000 \\
\hline Baker Hughes Inc & 1155000 & 12710093 & 11864000000 & 1955000000 & 1635000000 & 11861000000 \\
\hline Bank of NY Mellon & 993750 & 13288556 & 16339000000 & 16016000000 & 1419000000 & 237512000000 \\
\hline Black \& Decker & 1500000 & 13653766 & 6086100000 & 277800000 & 293600000 & 5183300000 \\
\hline Bristol-Myers & 1488077 & 5037768 & 20597000000 & 8265000000 & 5247000000 & 29552000000 \\
\hline Burlington N.S.F. & 1183583 & 5608233 & 18018000000 & 633000000 & 2115000000 & 36403000000 \\
\hline Comcast Corp & 2769365 & 28548 & 34256000000 & 000000 & 2547000000 & 113017000000 \\
\hline El Paso Corp & 1037505 & 6445 & 5363000000 & 00000 & -823000000 & 23668000000 \\
\hline EMC Corp & 1000000 & 12791608 & 14876200000 & 6807000000 & 1345600000 & 23874600000 \\
\hline Exelon Corp & 1474423 & & 18859000000 & & 2737000000 & 47817000000 \\
\hline Dow Chemica & 1641667 & & 57514000000 & & 00000 & 74000000 \\
\hline s Con & 1100000 & & 482300 & & 219 & 6000000 \\
\hline Merck \& Co & 1783334 & 30 & 238503 & 000 & 0000 & 47195700000 \\
\hline $\mathrm{i} C \mathrm{C}$ & 1300000 & & 432510 & 000 & 0000 & 35994000000 \\
\hline Pfizer & 1575 & & 482 & & & 18000000 \\
\hline Instruments & 963120 & & 125010 & & 000 & 11923000000 \\
\hline Time Warner & 1750000 & & & & -13402000000 & 113896000000 \\
\hline & 1318974 & & & & & 9000000 \\
\hline & 105 & & 405 & & & 9000000 \\
\hline $\mathrm{We}$ & 878920 & & 523 & & 000 & 9000000 \\
\hline & & & & & & 000 \\
\hline Arr & 1100 & & & & & 300000 \\
\hline & 945000 & & 0 & & & 5700000 \\
\hline BJ's's & 675000 & & 100 & & 000 & 021400000 \\
\hline Blue & 473077 & & & & & 732400000 \\
\hline & 110 & & & & & 000 \\
\hline & & & & & & 000 \\
\hline & 888 & & & & -78 & 3223900000 \\
\hline & & & & & & 7166000000 \\
\hline & 1275 & & & & & 9000000 \\
\hline CIT Group & 800000 & & & & 0000 & 8900000 \\
\hline Corm & 2769365 & & & & 0000 & 113017000000 \\
\hline & & & & & & 3071700000 \\
\hline & & & & & & \\
\hline & & & & & & \\
\hline & & & & & 000 & 26288000000 \\
\hline Eastr & 1131154 & & 6726000000 & & 346000000 & 5281000000 \\
\hline Ediso & 892485 & 3436 & 14112000000 & 449 & 1215000000 & 44615000000 \\
\hline Emco & 950000 & & 0000 & 0000 & 182200000 & 3008400000 \\
\hline Fith Third Banc & 899995 & & & 00000 & -2113000000 & 119764000000 \\
\hline FMC Technologi & & & & & & 3586300000 \\
\hline & & & & & & \\
\hline owen & & & & & 000 & 23353000000 \\
\hline & 1166667 & & & & $-6647 c$ & 7796800000 \\
\hline & & & 00 & & 000 & 3840400000 \\
\hline & 8750 & 71434 & 11015300000 & 00 & 475400000 & 4786400000 \\
\hline Hanover Insurance & 888461 & 21159 & 2680400000 & 416900000 & 20600000 & 9230200000 \\
\hline Holly Corp & 849782 & 3541910 & 5867700000 & 90000000 & 120600000 & 1874200000 \\
\hline Host Hotels \& Re & 750000 & 1682549 & 5288000000 & 552000000 & 427000000 & 11951000000 \\
\hline
\end{tabular}




\begin{tabular}{|c|c|c|c|c|c|c|}
\hline Interpublic Group & 1332500 & 10843080 & 6962700000 & 2325800000 & 295000000 & 12125200000 \\
\hline KB Home & 1000000 & 9624932 & 3033900000 & 1250800000 & -976100000 & 4044300000 \\
\hline Kelly Services & 917500 & 2035324 & 5517300000 & 118300000 & -82200000 & 1457300000 \\
\hline Key Corp & 1019538 & 4860595 & 6658000000 & 7758000000 & -1468000000 & 104531000000 \\
\hline Level 3 Com & 812692 & 5819886 & 4301000000 & 771000000 & -290000000 & 9638000000 \\
\hline Lexmark Int'l & 1007692 & 4246155 & 4528400000 & 973300000 & 240200000 & 3265400000 \\
\hline Eli Lilly \& Co & 1339125 & 12978215 & 20378000000 & 5926100000 & -2071900000 & 29212600000 \\
\hline Loews Corp & 1100000 & 7020135 & 14543000000 & 6160000000 & 4530000000 & 69857000000 \\
\hline MDC Holdings Inc & 1000000 & 9334163 & 1458100000 & 1360300000 & -380500000 & 2474900000 \\
\hline Manitowoc Co & 700000 & 4751527 & 4503000000 & 180700000 & -10700000 & 6065400000 \\
\hline Masco Corp & 934616 & 5516905 & 9600000000 & 1028000000 & -391000000 & 9483000000 \\
\hline Mirant Corp & 1127597 & 8637563 & 3188000000 & 4617000000 & 1265000000 & 10688000000 \\
\hline Mohawk Industries & 980000 & 1707822 & 6826400000 & 93500000 & -1458200000 & 6446200000 \\
\hline Murphy Oil Corp & 470833 & 2180163 & 27512500000 & 1086400000 & 1740000000 & 11149100000 \\
\hline Nash-Finch Co & 852937 & 5001958 & 4703700000 & 800000 & 36200000 & 955000000 \\
\hline Newell Rubbermaid & 1291667 & 5903527 & 6470600000 & 275400000 & -52300000 & 6792500000 \\
\hline Newmont Mining & 100000 & 5819737 & 6199000000 & 447000000 & 853000000 & 15839000000 \\
\hline Ni Source & 791667 & 2664531 & 3242600000 & 307200000 & 79000000 & 20032200000 \\
\hline Office Depot & 1000000 & 9361424 & 14495500000 & 155700000 & -1478900000 & 5268200000 \\
\hline OGE Energy Corp & 775000 & 3894891 & 4070700000 & 174400000 & 231400000 & 6518500000 \\
\hline Old Republic Int & 776146 & 880526 & 3237700000 & 951900000 & -558300000 & 13266000000 \\
\hline Omnicom Group Inc & c1000000 & 2953384 & 13359900000 & 1112400000 & 1000300000 & 17318400000 \\
\hline Owens \& Minor Inc & 788077 & 3595104 & 7243200000 & 7900000 & 93300000 & 1776200000 \\
\hline Peabody Energy & 1053750 & 11950858 & 6593400000 & 449700000 & 953500000 & 400000 \\
\hline JC Penney Co & 1500000 & 10023947 & 18846000000 & 2352000000 & 572000000 & 12011000000 \\
\hline Pepco Holding & 659375 & 2115469 & 10700000000 & 492000000 & 300000000 & 16475000000 \\
\hline Perini Corp & 493550 & 790600 & 5660300000 & 386300000 & -75100000 & 3073100000 \\
\hline PG \& E Corp & 1090833 & 13371479 & 14628000000 & 1342000000 & 1199000000 & 40537000000 \\
\hline PPG Industries & 1041667 & 8823450 & 15849000000 & 1045000000 & 538000000 & 14698000000 \\
\hline PPL Corp & 1141106 & 6676874 & 8044000000 & 1570000000 & 930000000 & 21405000000 \\
\hline Diagnostics & 1143868 & 32 & 00000 & 000 & 0000 & 8403800000 \\
\hline Qwest Comm & 1200000 & 104 & 00000 & 565 & 000 & 20182000000 \\
\hline CH Robinson World & d 400000 & 4393 & 3600000 & 497400000 & 359200000 & 1815700000 \\
\hline Ross Stores Inc & 1031238 & 8208732 & 6486100000 & 322100000 & 305400000 & 2355500000 \\
\hline Ryder System Inc & 895000 & 4696052 & 6203700000 & 152800000 & 199900000 & 6689500000 \\
\hline Saks Inc & 1060000 & 3099006 & 3029700000 & 10300000 & -154900000 & 2165000000 \\
\hline Scana Corp & 1094985 & 6821202 & 5319000000 & 272000000 & 346000000 & 11502000000 \\
\hline Henry Schein Inc & 1123462 & 3722320 & 6394900000 & 374900000 & 243100000 & 3599600000 \\
\hline Sem & 1143957 & 11979186 & 107 & 6940 & 1113 & 00000 \\
\hline Illiams & 1214590 & 6203510 & 00000 & 26200000 & 476900000 & 4415800000 \\
\hline st Airlines & 441121 & 1680272 & 11023000000 & 1803000000 & 178000000 & 14308000000 \\
\hline Staples Inc & 1112000 & 8377420 & 23083800000 & 633800000 & 805300000 & 13006000000 \\
\hline Temple Inland Inc & 774538 & 1905417 & 3884000000 & 41000000 & -8000000 & 5869000000 \\
\hline Gap Inc & 1500000 & 9329170 & 14526000000 & 1756000000 & 967000000 & 7564000000 \\
\hline Timken Co & 1018840 & 5740669 & 5663700000 & 116300000 & 267700000 & 4536000000 \\
\hline Travel Centers & 300000 & 1727440 & 7658400000 & 145500000 & -40200000 & 889800000 \\
\hline UAL Corp & 850000 & 6471062 & 20194000000 & 3046000000 & -5348000000 & 19461000000 \\
\hline Union Pacific & 1141667 & 7428212 & 17970000000 & 1249000000 & 2338000000 & 39722000000 \\
\hline Universal American & 857444 & 3503702 & 4659200000 & 511000000 & 95100000 & 3870700000 \\
\hline Wesco Int’l & 854167 & 4619395 & 6110800000 & 86300000 & 212700000 & 2721000000 \\
\hline Wisconsin Energy & 1129008 & 9875302 & 4431000000 & 246600000 & 359100000 & 12617800000 \\
\hline XTO Energy & 941674 & 29722888 & 7695000000 & 2760000000 & 1912000000 & 38254000000 \\
\hline
\end{tabular}


DESCRIPTIVES VARIABLES=Salary TotalCompensation returns CashFlows Earnings Assets /STATISTICS=MEAN STDDEV MIN MAX.

\section{Descriptives}

Notes

\begin{tabular}{|c|c|c|}
\hline \multicolumn{2}{|l|}{$\begin{array}{l}\text { Output Created } \\
\text { Comments }\end{array}$} & 14-May-2009 20:15:37 \\
\hline \multirow[t]{6}{*}{ Input } & Data & E: lceodata.sav \\
\hline & Active Dataset & DataSet1 \\
\hline & Filter & $\mid<$ none $>$ \\
\hline & Weight & | none $\rangle$ \\
\hline & Split File & <none $>$ \\
\hline & $\mathrm{N}$ of Rows in Working Data File & 103 \\
\hline \multirow[t]{2}{*}{ Missing Value Handling } & Definition of Missing & $\begin{array}{l}\text { User defined missing values are treated as } \\
\text { missing. }\end{array}$ \\
\hline & Cases Used & All non-missing data are used. \\
\hline Syntax & & \begin{tabular}{lcr} 
DESCRIPTIVES & \multicolumn{2}{c}{ VARIABLES=Salary } \\
TotalCompensation & returns & CashFlows \\
Earnings Assets & & \\
/STATISTICS=MEAN STDDEV MIN MAX.
\end{tabular} \\
\hline \multirow[t]{2}{*}{ Resources } & Processor Time & 0:00:00.000 \\
\hline & Elapsed Time & 0:00:00.000 \\
\hline
\end{tabular}

[DataSet1] E:Iceodata.sav

\section{Descriptive Statistics}

\begin{tabular}{|l|c|c|c|c|c|}
\hline \multicolumn{7}{|c|}{ Descriptive Statistics } \\
\hline & $\mathbf{N}$ & Minimum & Maximum & Mean & Std. Deviation \\
\hline Salary & 103 & 100000 & 2769365 & 1058389.50 & 412216.857 \\
\hline Total Compensation & 103 & 790600 & 33386016 & 8530533.29 & 6502853.978 \\
\hline returns & 103 & 4970.00 & 4056070.00 & 166606.6505 & $4.06231 \mathrm{E} 5$ \\
\hline CashFlows & 103 & 8.00 & 1160160.00 & 36047.6505 & $1.35676 \mathrm{E} 5$ \\
\hline Earnings & 103 & -134020.00 & 134000.00 & 5471.9126 & 29378.55680 \\
\hline Assets & 103 & 7324.00 & 13096390.00 & 414485.0097 & $1.37315 \mathrm{E} 6$ \\
\hline Valid N (listwise) & 103 & & & & \\
\hline
\end{tabular}

Note: For ease of data reading, the variables Returns, Cash flow, Earning and Asset are divided by 100000 
REGRESSION /MISSING LISTWISE /STATISTICS COEFF OUTS R ANOVA COLLIN TOL CHANGE /CRITERIA=PIN(.05) POUT(.10) /NOORIGIN /DEPENDENT ChangeCompensation /METHOD=BACKWARD ChangeInReturn ChangeInCashFlow ChangeInEarning ChangeInAsset.

\section{Regression}

\begin{tabular}{|c|c|c|}
\hline \multicolumn{3}{|c|}{ Notes } \\
\hline \multicolumn{2}{|l|}{ Output Created } & 11-May-2009 22:27:36 \\
\hline \multicolumn{2}{|l|}{ Comments } & \\
\hline \multirow[t]{6}{*}{ Input } & Data & E:Iceodata1.sav \\
\hline & Active Dataset & DataSet0 \\
\hline & Filter & $\mid$ none $\rangle$ \\
\hline & Weight & <none $>$ \\
\hline & Split File & $\langle$ none $>$ \\
\hline & $\mathrm{N}$ of Rows in Working Data File & 103 \\
\hline \multirow[t]{2}{*}{ Missing Value Handling } & Definition of Missing & User-defined missing values are treated as missing. \\
\hline & Cases Used & $\begin{array}{l}\text { Statistics are based on cases with no missing values } \\
\text { for any variable used. }\end{array}$ \\
\hline \multicolumn{2}{|l|}{ Syntax } & $\begin{array}{l}\text { REGRESSION } \\
\text { /MISSING LISTWISE } \\
\text { /STATISTICS COEFF OUTS R ANOVA } \\
\text { COLLIN TOL CHANGE } \\
\text { /CRITERIA=PIN(.05) POUT(.10) } \\
\text { /NOORIGIN } \\
\text { /DEPENDENT ChangeCompensation } \\
\text { /METHOD=BACKWARD ChangeInReturn } \\
\text { ChangeInCashFlow } \\
\text { ChangeInAsset. }\end{array}$ \\
\hline \multirow[t]{4}{*}{ Resources } & Processor Time & 0:00:00.078 \\
\hline & Elapsed Time & 0:00:00.078 \\
\hline & Memory Required & 2628 bytes \\
\hline & \begin{tabular}{|l} 
Additional Memory Required for \\
Residual Plots
\end{tabular} & 0 bytes \\
\hline
\end{tabular}

[DataSet0] E:Iceodata1.sav

\begin{tabular}{|c|c|c|c|}
\hline \multicolumn{4}{|c|}{ Variables Entered/Removed $^{\text {b }}$} \\
\hline Model & Variables Entered & Variables Removed & Method \\
\hline 1 & $\begin{array}{l}\text { ChangeInAsset, ChangeInEarning, } \\
\text { ChangeInReturn, } \\
\text { ChangeInCashFlow }^{\text {a }}\end{array}$ & & Enter \\
\hline 2 & . & ChangeInCashFlow & $\begin{array}{l}\text { Backward (criterion: Probability } \\
\text { of F-to-remove }>=.100 \text { ). }\end{array}$ \\
\hline 3 & . & ChangeInReturn & $\begin{array}{l}\text { Backward (criterion: Probability } \\
\text { of F-to-remove }>=.100 \text { ). }\end{array}$ \\
\hline 4 & . & ChangeInEarning & $\begin{array}{l}\text { Backward (criterion: Probability } \\
\text { of F-to-remove }>=.100 \text { ). }\end{array}$ \\
\hline \multicolumn{4}{|c|}{ a. All requested variables entered. } \\
\hline \multicolumn{4}{|c|}{ b. Dependent Variable: ChangeCompensation } \\
\hline
\end{tabular}




\begin{tabular}{|c|c|c|c|c|c|c|c|c|c|}
\hline \multicolumn{10}{|c|}{ Model Summary } \\
\hline \multirow[b]{2}{*}{ Model } & \multirow[b]{2}{*}{$\mathrm{R}$} & \multirow[b]{2}{*}{ R Square } & \multirow[b]{2}{*}{$\begin{array}{l}\text { Adjusted R } \\
\text { Square }\end{array}$} & \multirow[b]{2}{*}{$\begin{array}{l}\text { Std. Error of } \\
\text { the Estimate }\end{array}$} & \multicolumn{5}{|c|}{ Change Statistics } \\
\hline & & & & & $\begin{array}{c}\text { R Square } \\
\text { Change } \\
\end{array}$ & F Change & df1 & $\mathrm{df} 2$ & Sig. F Change \\
\hline 1 & $.263^{\mathrm{a}}$ & .069 & .031 & 6.46008 & .069 & 1.814 & 4 & 98 & .132 \\
\hline 2 & $.262^{\mathrm{b}}$ & .069 & .041 & 6.42768 & .000 & .009 & 1 & 98 & .923 \\
\hline 3 & $.262^{\mathrm{c}}$ & .069 & .050 & 6.39627 & .000 & .025 & 1 & 99 & .875 \\
\hline 4 & $.260^{\mathrm{d}}$ & .067 & .058 & 6.36869 & -.001 & .131 & 1 & 100 & .718 \\
\hline \multicolumn{10}{|c|}{ a. Predictors: (Constant), ChangeInAsset, ChangeInEarning, ChangeInReturn, ChangeInCashFlow } \\
\hline \multicolumn{10}{|c|}{ b. Predictors: (Constant), ChangeInAsset, ChangeInEarning, ChangeInReturn } \\
\hline \multicolumn{10}{|c|}{ c. Predictors: (Constant), ChangeInAsset, ChangeInEarning } \\
\hline \multicolumn{10}{|c|}{ d. Predictors: (Constant), ChangeInAsset } \\
\hline
\end{tabular}

\begin{tabular}{|c|c|c|c|c|c|c|}
\hline \multicolumn{7}{|c|}{ ANOVA $^{\mathrm{e}}$} \\
\hline & Model & Sum of Squares & df & Mean Square & $\mathrm{F}$ & Sig. \\
\hline \multirow[t]{3}{*}{1} & Regression & 302.842 & 4 & 75.711 & 1.814 & $.132^{\mathrm{a}}$ \\
\hline & Residual & 4089.802 & 98 & 41.733 & & \\
\hline & Total & 4392.645 & 102 & & & \\
\hline \multirow[t]{3}{*}{2} & Regression & 302.450 & 3 & 100.817 & 2.440 & $.069^{\mathrm{b}}$ \\
\hline & Residual & 4090.195 & 99 & 41.315 & & \\
\hline & Total & 4392.645 & 102 & & & \\
\hline \multirow[t]{3}{*}{3} & Regression & 301.422 & 2 & 150.711 & 3.684 & $.029^{\mathrm{c}}$ \\
\hline & Residual & 4091.222 & 100 & 40.912 & & \\
\hline & Total & 4392.645 & 102 & & & \\
\hline \multirow[t]{3}{*}{4} & Regression & 296.065 & 1 & 296.065 & 7.299 & $.008^{\mathrm{d}}$ \\
\hline & Residual & 4096.580 & 101 & 40.560 & & \\
\hline & Total & 4392.645 & 102 & & & \\
\hline \multicolumn{7}{|c|}{ a. Predictors: (Constant), ChangeInAsset, ChangeInEarning, ChangeInReturn, ChangeInCashFlow } \\
\hline \multicolumn{7}{|c|}{ b. Predictors: (Constant), ChangeInAsset, ChangeInEarning, ChangeInReturn } \\
\hline \multicolumn{7}{|c|}{ c. Predictors: (Constant), ChangeInAsset, ChangeInEarning } \\
\hline \multicolumn{7}{|c|}{ d. Predictors: (Constant), ChangeInAsset } \\
\hline \multicolumn{7}{|c|}{ e. Dependent Variable: ChangeCompensation } \\
\hline
\end{tabular}




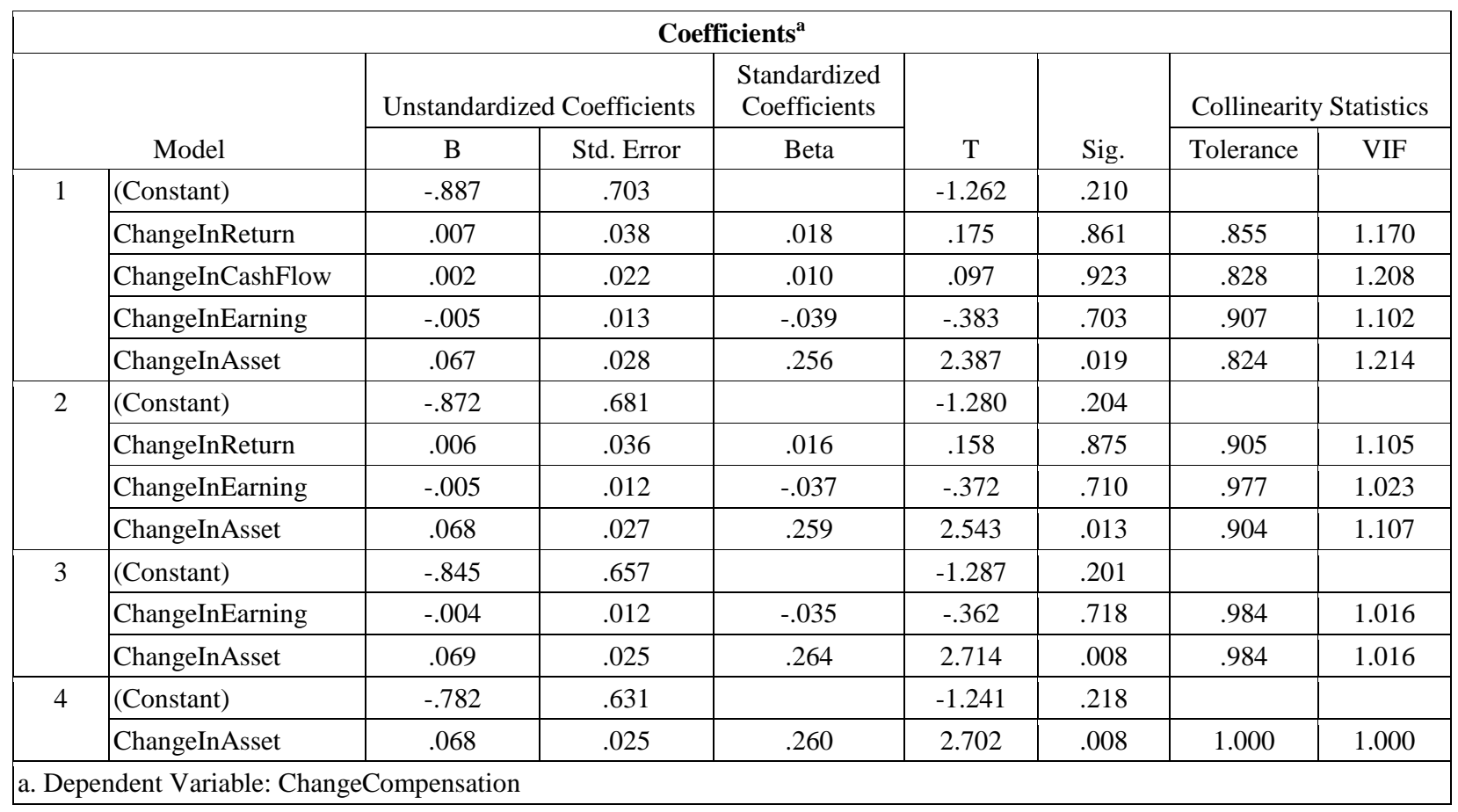

\begin{tabular}{|c|c|c|c|c|c|c|c|c|}
\hline \multicolumn{9}{|c|}{ Collinearity Diagnostics ${ }^{\mathrm{a}}$} \\
\hline \multirow[b]{2}{*}{ Model } & \multirow[b]{2}{*}{ Dimension } & \multirow[b]{2}{*}{ Eigenvalue } & \multirow{2}{*}{$\begin{array}{c}\text { Condition } \\
\text { Index }\end{array}$} & \multicolumn{5}{|c|}{ Variance Proportions } \\
\hline & & & & (Constant) & ChangeInReturn & ChangeInCashFlow & ChangeInEarning & ChangeInAsset \\
\hline \multirow[t]{5}{*}{1} & 1 & 1.523 & 1.000 & .09 & .14 & .09 & .01 & .21 \\
\hline & 2 & 1.329 & 1.071 & .16 & .04 & .11 & .30 & .01 \\
\hline & 3 & .999 & 1.235 & .13 & .27 & .32 & .08 & .01 \\
\hline & 4 & .712 & 1.462 & .25 & .07 & .00 & .34 & .50 \\
\hline & 5 & .437 & 1.866 & .37 & .48 & .47 & .28 & .27 \\
\hline \multirow[t]{4}{*}{2} & 1 & 1.458 & 1.000 & .17 & .24 & & .01 & .17 \\
\hline & 2 & 1.217 & 1.094 & .16 & .03 & & .44 & .12 \\
\hline & 3 & .716 & 1.426 & .15 & .17 & & .31 & .62 \\
\hline & 4 & .608 & 1.548 & .52 & .57 & & .25 & .09 \\
\hline \multirow[t]{3}{*}{3} & 1 & 1.252 & 1.000 & .37 & & & .36 & .00 \\
\hline & 2 & 1.061 & 1.086 & .06 & & & .08 & .77 \\
\hline & 3 & .686 & 1.351 & .56 & & & .56 & .23 \\
\hline \multirow[t]{2}{*}{4} & 1 & 1.101 & 1.000 & .45 & & & & .45 \\
\hline & 2 & .899 & 1.107 & .55 & & & & .55 \\
\hline
\end{tabular}




\begin{tabular}{|c|c|c|c|c|c|c|c|c|}
\hline \multicolumn{9}{|c|}{ Excluded Variables $^{d}$} \\
\hline \multirow{2}{*}{\multicolumn{2}{|c|}{ Model }} & \multirow[b]{2}{*}{ Beta In } & \multirow[b]{2}{*}{$\mathrm{T}$} & \multirow[b]{2}{*}{ Sig. } & \multirow[b]{2}{*}{$\begin{array}{c}\text { Partial } \\
\text { Correlation }\end{array}$} & \multicolumn{3}{|c|}{ Collinearity Statistics } \\
\hline & & & & & & Tolerance & VIF & $\begin{array}{l}\text { Minimum } \\
\text { Tolerance }\end{array}$ \\
\hline 2 & ChangeInCashFlow & $.010^{\mathrm{a}}$ & .097 & .923 & .010 & .828 & 1.208 & .824 \\
\hline \multirow[t]{2}{*}{3} & ChangeInCashFlow & $.006^{\mathrm{b}}$ & .057 & .954 & .006 & .877 & 1.140 & .877 \\
\hline & ChangeInReturn & $.016^{\mathrm{b}}$ & .158 & .875 & .016 & .905 & 1.105 & .904 \\
\hline \multirow[t]{3}{*}{4} & ChangeInCashFlow & $-.003^{c}$ & -.032 & .975 & -.003 & .932 & 1.073 & .932 \\
\hline & ChangeInReturn & $.013^{\mathrm{c}}$ & .127 & .899 & .013 & .912 & 1.097 & .912 \\
\hline & ChangeInEarning & $-.035^{\mathrm{c}}$ & -.362 & .718 & -.036 & .984 & 1.016 & .984 \\
\hline \multicolumn{9}{|c|}{ a. Predictors in the Model: (Constant), ChangeInAsset, ChangeInEarning, ChangeInReturn } \\
\hline \multicolumn{9}{|c|}{ b. Predictors in the Model: (Constant), ChangeInAsset, ChangeInEarning } \\
\hline \multicolumn{9}{|c|}{ c. Predictors in the Model: (Constant), ChangeInAsset } \\
\hline \multicolumn{9}{|c|}{ d. Dependent Variable: ChangeCompensation } \\
\hline
\end{tabular}

